\title{
ТЕХНОЛОГІЧНІ АСПЕКТИ ОТРИМАННЯ ЕКСТРАКТУ З КВІТОК ХРИЗАНТЕМИ САДОВОЇ СОРТУ ПЕКТОРАЛЬ
}

Вступ. Хронічний стрес, роздратованість та порушення сну знижують якість життя людини, послаблюють імунітет, підвищують ризик розвитку різних запальних захворювань. Тому зростає попит на лікарські засоби рослинного походження і виникає необхідність розширити їх асортимент. Іноземні джерела свідчать про перспективність використання квіток хризантеми як седативного та протисудомного засобу. Через че перспективною була розробка технології отримання екстракту з квіток хризантеми садової.

Мета дослідження - вивчити вплив деяких фрармацевтичних фракторів на ступінь вилучення діючих речовин із квіток хризантеми садової сорту Пектораль для розробки технології отримання сухого екстракту на основі цієї рослини, який у подальшому використовуватимуть як напівпродукт у виробництві нових лікарських фрорм.

Методи дослідження. Вивчено вплив на ступінь вилучення біологічно активних речовин таких фрармацевтичних фракторів, як природа екстрагенту, співвідношення вихідна сировина/екстрагент і метод екстрагування. Критеріями оцінки отриманих сухих субстанцій слугували кількісний вміст суми френольних сполук (перерахунок на галову кислоту), кількісний вміст суми фрлавоноїдів (перерахунок на рутин) та кількісний вміст суми гідроксикоричних кислот (перерахунок нахлорогенову кислоту), які визначали спектрофротометричним методом на спектрофотометрі Lambda 25 Perkin Elmer.

Результати й обговорення. На основі математичного планування експерименту вивчено закономірності вилучення френольних сполук, фрлавоноїдів та гідроксикоричних сполук із квіток хризантеми садової сорту Пектораль залежно від концентрації використаного екстрагенту етанолу, співвідношення сировина/екстрагент і методу екстрагування.

Висновок. Встановлено, що оптимальним способом отримання екстракту з квіток хризантеми садової сорту Пектораль є метод дробної мацерації 70 \% етанолом при співвідношенні лікарська рослинна сировина/екстрагент 1:8.

КЛЮЧОВІ СЛОВА: хризантема садова; квітки; екстракт; технологічні параметри.

ВСТУП. Інформаційна перенасиченість, велике навантаження на роботі, побутові конорлікти й інші фактори викликають хронічний стрес, роздратованість і порушення сну, що, у свою чергу, знижують якість життя людини, послаблюють імунітет, підвищують ризик розвитку різних запальних захворювань. Це особливо актуально на даний час, враховуючи пандемію COVID-19. Складність і підступність цієї хвороби проявляються ще й постковідним синдромом (англ. post COVID-19 sindrom/“Long Covid"), що супроводжується конгітивними порушеннями (втрата пам'яті, “туман у голові", дезорієнтація в просторі, тривога, панічні атаки, суїцидальні думки/ спроби, стрес). Тому зростає попит на лікарські засоби рослинного походження і виникає необхідність розширити асортимент екстракційних () Г. Р. Козир, Ю. В. Каріна, 2021. препаратів 3 лікарської рослинної сировини [1, 2], зокрема екстракційних препаратів із седативною та протизапальною дією, для корекції невротичних і неврозоподібних розладів та запальних захворювань, викликаних ними.

Нашу увагу привернула хризантема садова, що належить до роду квіткових рослин з родини айстрових (Asteraceae), або складноцвітих (Compositae).

Відомо, що в Японії, Китаї, Монголії хризантема - це лікувальна рослина.

У китайській народній медицині листки хризантеми використовують для полегшення головного болю, болю в горлі, висушені квітки - 3 метою покращення апетиту. В деяких країнах листки і квітки рослини застосовують для лікування захворювань очей, алкоголізму, малярії, головного болю невралгічного характеру, гіпер- 
тензії та для поліпшення циркуляції кровотоку, проорілактики серцево-судинних захворювань і захворювань шлунково-кишкового тракту; зовнішньо - при абсцесах та фрурункулах, пародонтозі. Хризантема сприяє підвищенню імунітету, знижує рівень холестерину і цукру, є заспокійливим та жарознижувальним засобом [3-7].

Мета дослідження - вивчити вплив деяких фрармацевтичних фракторів на ступінь вилучення діючих речовин із квіток хризантеми садової сорту Пектораль для розробки технології отримання сухого екстракту на основі цієї рослини, який у подальшому використовуватимуть як напівпродукт у виробництві нових лікарських фрорм.

МЕТОДИ ДОСЛІДЖЕННЯ. Об'єКТом дОслідження вибрано квітки хризантеми садової сорту Пектораль, вирощеної на дослідній ділянці HOK "Червона калина" Тернопільського національного медичного університету імені І. Я. Горбачевського МОЗ України. Сировину подрібнювали за допомогою лабораторного млина лзМ та просіювали через набір сит просіювача DZ-200 з таймером. Для розробки оптимальної технології отримання екстракту з квіток хризантеми садової сорту Пектораль ми провели серію дослідів. 3 метою вивчення впливу природи екстрагенту на вилучення біологічно активних речовин із квіток цієї рослини використовували етанол у концентрації 50, 60, 70 та 75 \%. Досліджували вплив на ступінь вилучення біологічно активних речовин такого фрармацевтичного фрактора, як співвідношення вихідна сировина/ екстрагент. Для цього було вибрано діапазон співвідношення від 1:5 до 1:12.

Екстрагування проводили такими методами, як мацерація, примусова мацерація, дробна мацерація та мацерація 3 ультразвуковою екстракцією (УЗЕ) 3 використанням апарата "Ultrasonic UC-50" (43kHz). Критеріями оцінки отриманих сухих субстанцій слугували кількісний вміст суми френольних сполук (перерахунок на галову кислоту), кількісний вміст суми фрлавоноїдів (перерахунок на рутин) та кількісний вміст суми гідроксикоричних кислот (перерахунок на хлорогенову кислоту), які визначали за методиками ДФУ [8] спектрофотометричним методом на спектрофотометрі Lambda 25 Perkin Elmer y кюветах з товщиною шару 10 мм. Оптичну густину гідроксикоричних кислот визначали при довжині хвилі 327 нм у перерахунку на хлорогенову кислоту, кількісний вміст суми фрлавоноїдів та суми фенольних сполук - при довжині хвилі 410 нм у перерахунку на рутин і при довжині хвилі 290 нм у перерахунку на галову кислоту відповідно.
РЕЗУЛЬТАТИ Й ОБГОВОРЕННЯ. 3 МеТОЮ вивчення впливу фрармацевтичних фракторів на ступінь вилучення біологічно активних речовин із квіток хризантеми садової сорту Пектораль використано трифракторний дробний план на основі латинського квадрата 4×4 [9]. Фактори та їх рівні, які досліджували для оптимізації екстракту з квіток хризантеми садової сорту Пектораль, наведено в таблиці 1.

\section{Таблиця 1 - Фактори та їх рівні, які досліджували для оптимізації екстракту з квіток хризантеми садової сорту Пектораль}

\begin{tabular}{||l|c||}
\hline \multicolumn{1}{|c|}{ Фактор } & Рівень фрактора \\
\hline A - екстрагент & $\mathrm{a}_{1}-$ етанол $50 \%$ \\
& $\mathrm{a}_{2}-$ етанол $60 \%$ \\
& $\mathrm{a}_{3}$ - етанол $70 \%$ \\
& $\mathrm{a}_{4}-$ етанол $75 \%$ \\
\hline В - співвідношення & $\mathrm{b}_{1}-1: 5$ \\
сировина/екстрагент & $\mathrm{b}_{2}-1: 8$ \\
& $\mathrm{~b}_{3}-1: 10$ \\
& $\mathrm{~b}_{4}-1: 12$ \\
\hline С-методи & $\mathrm{c}_{1}-$ мацерація \\
екстрагування & $\mathrm{c}_{2}-$ примусова мацерація \\
& $\mathrm{c}_{3}-$ дробна мацерація \\
& $\mathrm{c}_{4}-$ мацерація з УзЕ \\
\hline
\end{tabular}

Для вивчення впливу трьох фракторів на чотирьох рівнях доцільно використати латинський квадрат 4×4. Матрицю планування експерименту для латинського квадрата $4 \times 4$ і результати досліджень екстрактів на вміст френольних сполук (перерахунок на галову кислоту), фрлавоноїдів (перерахунок на рутин) та гідроксикоричних кислот (перерахунок на хлорогенову кислоту) наведено в таблиці 2.

Для опрацювання результатів досліджень було складено програму в режимі Excel, що дозволило оперативно здійснювати їх статистичну обробку.

Відомо, що ефективність процесу екстрагування діючих речовин з рослинної сировини значною мірою залежить від технологічних характеристик самого матеріалу, срізико-хімічних властивостей екстрагенту і біологічно активних речовин, які вилучають, режимів та методів екстракції [10-12]. Тому з метою оптимізації технології отримання екстракту з квіток хризантеми садової сорту Пектораль ми вивчали вплив такого фрактора, як співвідношення лікарська рослинна сировина/екстрагент. Для цього використовували в дослідженнях серії з діапазоном від 1:5 до 1:12. При вивченні впливу співвідношення лікарська рослинна сировина/екстрагент на вилучення суми фенольних сполук, суми фрлавоноїдів та суми гідроксикоричних кислот найвищий вміст цих сполук одержали при співвідношенні 1:8 (рис. 1). Тому для подальших 
Таблиця 2 - Трифакторний дробний план експерименту на основі латинського квадрата 4×4 і результати досліджень екстрактів

\begin{tabular}{||c|c|c|c|c|c|c|}
\hline № cepiï & $\mathrm{A}$ & $\mathrm{B}$ & $\mathrm{C}$ & $\mathrm{y}_{1}$ & $\mathrm{y}_{2}$ & $\mathrm{y}_{3}$ \\
\hline 1 & $\mathrm{a}_{1}$ & $\mathrm{~b}_{1}$ & $\mathrm{c}_{1}$ & 3,02 & 2,74 & 2,02 \\
\hline 2 & $\mathrm{a}_{1}$ & $\mathrm{~b}_{2}$ & $\mathrm{c}_{2}$ & 5,10 & 6,19 & 2,26 \\
\hline 3 & $\mathrm{a}_{1}$ & $\mathrm{~b}_{3}$ & $\mathrm{c}_{4}$ & 3,90 & 2,51 & 2,37 \\
\hline 4 & $\mathrm{a}_{1}$ & $\mathrm{~b}_{4}$ & $\mathrm{c}_{3}$ & 6,44 & 3,32 & 2,40 \\
\hline 5 & $\mathrm{a}_{2}$ & $\mathrm{~b}_{1}$ & $\mathrm{c}_{2}$ & 5,59 & 3,00 & 2,09 \\
\hline 6 & $\mathrm{a}_{2}$ & $\mathrm{~b}_{2}$ & $\mathrm{c}_{1}$ & 4,97 & 3,16 & 2,69 \\
\hline 7 & $\mathrm{a}_{2}$ & $\mathrm{~b}_{3}$ & $\mathrm{c}_{3}$ & 6,26 & 3,06 & 2,23 \\
\hline 8 & $\mathrm{a}_{2}$ & $\mathrm{~b}_{4}$ & $\mathrm{c}_{4}$ & 4,12 & 3,31 & 2,27 \\
\hline 9 & $\mathrm{a}_{3}$ & $\mathrm{~b}_{1}$ & $\mathrm{c}_{3}$ & 5,59 & 4,67 & 2,49 \\
\hline 10 & $\mathrm{a}_{3}$ & $\mathrm{~b}_{2}$ & $\mathrm{c}_{4}$ & 4,31 & 1,59 & 3,24 \\
\hline 11 & $\mathrm{a}_{3}$ & $\mathrm{~b}_{3}$ & $\mathrm{c}_{1}$ & 4,59 & 3,65 & 2,57 \\
\hline 12 & $\mathrm{a}_{3}$ & $\mathrm{~b}_{4}$ & $\mathrm{c}_{2}$ & 4,03 & 3,93 & 2,29 \\
\hline 13 & $\mathrm{a}_{4}$ & $\mathrm{~b}_{1}$ & $\mathrm{c}_{4}$ & 4,29 & 3,38 & 2,54 \\
\hline 14 & $\mathrm{a}_{4}$ & $\mathrm{~b}_{2}$ & $\mathrm{c}_{3}$ & 4,52 & 4,50 & 2,89 \\
\hline 15 & $\mathrm{a}_{4}$ & $\mathrm{~b}_{3}$ & $\mathrm{c}_{2}$ & 3,98 & 3,96 & 2,41 \\
\hline 16 & $\mathrm{a}_{4}$ & $\mathrm{~b}_{4}$ & $\mathrm{c}_{1}$ & 3,30 & 4,67 & 2,25 \\
\hline
\end{tabular}

Примітка: у
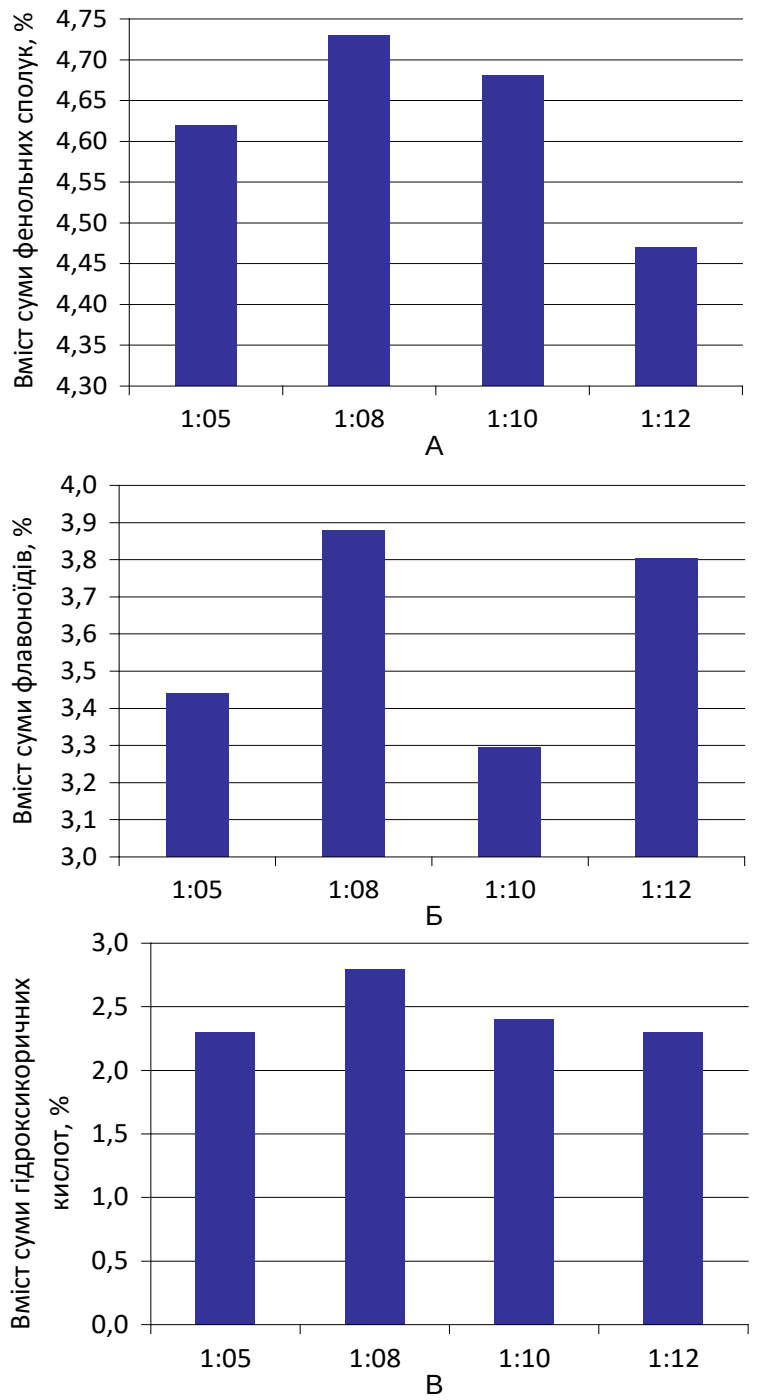

Рис. 1. Діаграма залежності вмісту суми фенольних сполук (А), суми фрлавоноїдів (Б) та суми гідроксикоричних кислот (В) від співвідношення лікарська рослинна сировина/екстрагент. досліджень будемо застосовувати саме таку кількість.

При розробці технології отримання екстракту з квіток хризантеми садової сорту Пектораль вивчали вплив методу одержання витяжки. Для цього було використано такі методи, як мацерація, примусова мацерація, дробна мацерація та мацерація з УЗЕ.

Згідно з одержаними результатами, найвищий вміст гідроксикоричних кислот в отриманому екстракті забезпечував метод мацерації з УЗЕ (рис. 2). Майже не поступався йому метод дробної мацерації, при використанні якого вміст гідроксикоричних кислот був лише на 0,1\% меншим. Експериментально встановлено, що найгіршим виявився метод примусової мацерації.

Для вилучення суми френольних сполук найкращим виявився метод дробної мацерації (рис. 3). При цьому максимальний вміст суми френольних сполук у витяжках із квітів хризантеми садової становив 5,703 \%, мінімальну кількість (3,97 \%) отримано методом мацерації.

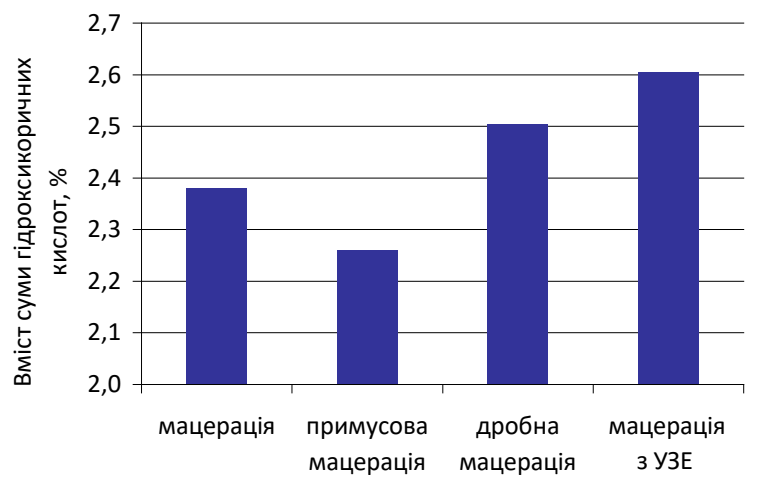

Рис. 2. Діаграма залежності вмісту суми гідроксикоричних кислот від методу отримання субстанції. 
Згідно 3 результатами проведених досліджень, вилучення суми срлавоноїдів найкраще забезпечувало використання методу примусової мацерації (рис. 4). Дробна мацерація забезпечувала лише на 0,38 \% гірші результати, ніж попередній метод. Найменша кількість суми флавоноїдів вилучається методом мацерації 3 УЗЕ.

На підставі проведеного аналізу результатів досліджень встановлено, що метод дробної мацерації найкраще забезпечує вилучення суми гідроксикоричних кислот, суми фенольних сполук та високий вміст суми фрлавоноїдів, при цьому дозволяє більш повно виснажити лікарську рослинну сировину за менший період часу. Тому для подальших досліджень вибрано саме метод дробної мацерації.

При вивченні впливу екстрагенту на ступінь вилучення біологічно активних речовин, а саме гідроксикоричних кислот, із квіток хризантеми садової сорту Пектораль було встановлено, що максимальна кількість гідроксикоричних кислот екстрагувалася 70 \% етанолом, що становило $2,65 \%$, та $75 \%$ етанолом, що складало 2,52 \% відповідно (рис. 5). Найменша кількість досліджуваних речовин вилучалася 50 \% етанолом.

Залежність ступеня вилучення суми фенольних сполук із лікарської рослинної сировини від вибору екстрагенту зображено на рисунку 6.

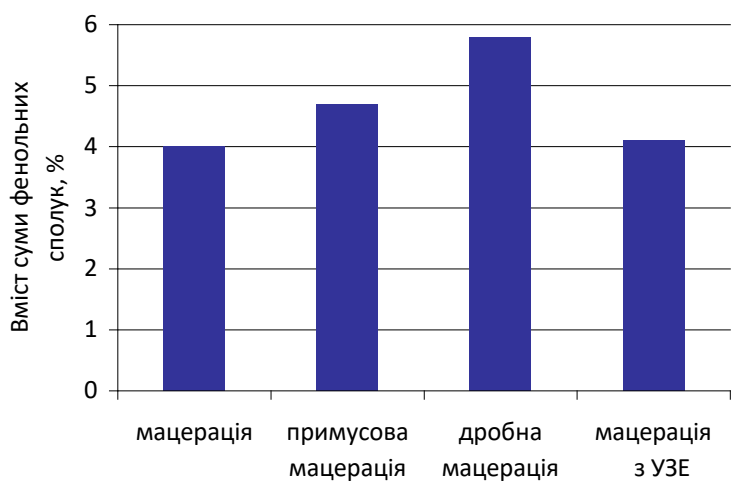

Рис. 3. Діаграма залежності вмісту суми фенольних сполук від методу отримання субстанції.

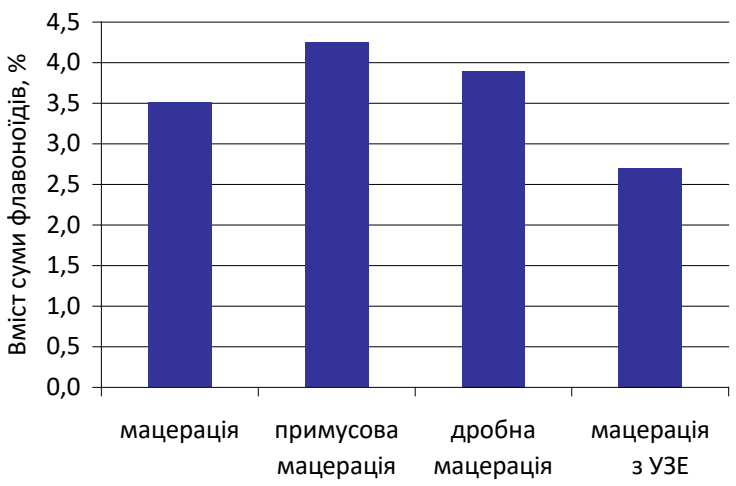

Рис. 4. Діаграма залежності вмісту суми фрлавоноїдів від методу отримання субстанції.
Як видно з рисунка 6, максимальне значення суми фенольних сполук становило 5,235 \% при використанні 60 \% етанолу. Подальше зростання концентрації екстрагенту привело до зниження вмісту френольних сполук, причому найменша їх кількість вилучалася при використанні $75 \%$ спирту - 4,022 \%.

При вивченні впливу екстрагенту на ступінь вилучення біологічно активних речовин, а саме суми срлавоноїдів, із квіток хризантеми садової сорту Пектораль було встановлено, що максимальний вміст суми фрлавоноїдів досягався екстрагуванням 75 та 50 \% етанолом, що становило 4,13 і 3,69 \% відповідно (рис. 7). Найменшу кількість досліджуваних речовин одержували при екстрагуванні 60 \% етанолом.

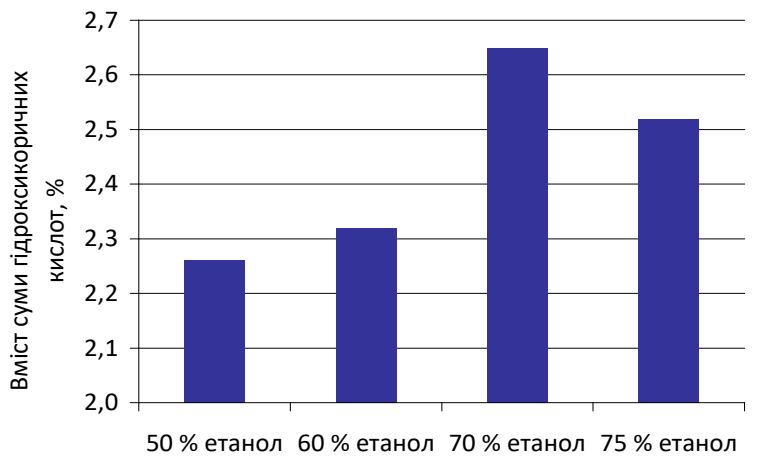

Рис. 5. Діаграма залежності вмісту суми гідроксикоричних кислот від концентрації екстрагенту.

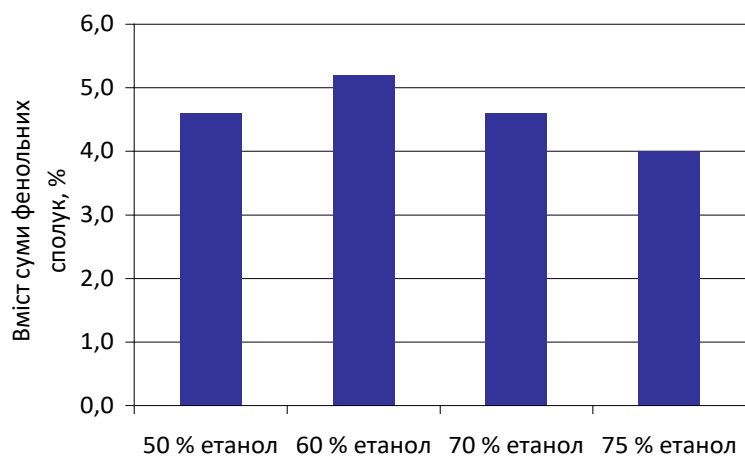

Рис. 6. Діаграма залежності вмісту суми фенольних сполук від виду екстрагенту.

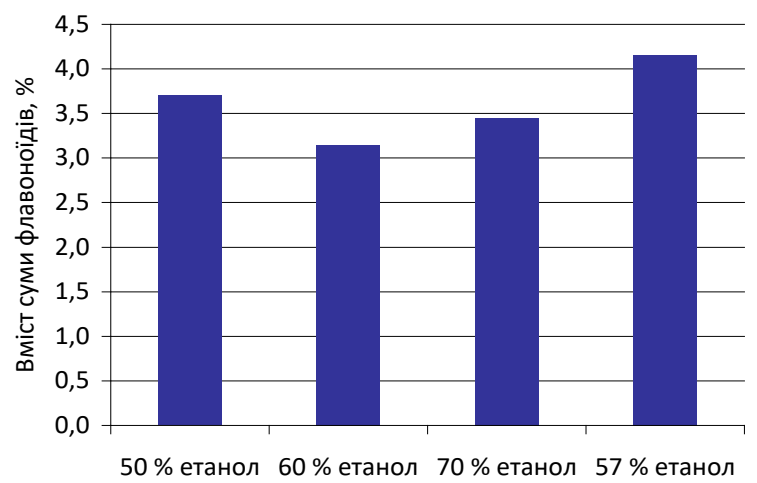

Рис. 7. Діаграма залежності вмісту суми фрлавоноїдів від виду екстрагенту. 
Оскільки одержані результати не дали змоги чітко встановити необхідну концентрацію екстрагенту для отримання екстракту з квіток хризантеми садової сорту Пектораль, ми провели додаткові дослідження.

Екстрагентом був етанол у концентрації 60, $63,65,68,70,73$ та 75 \%. Екстракт із квіток хризантеми садової сорту Пектораль отримували методом дробної мацерації при співвідношенні лікарська рослинна сировина/екстрагент 1:8. Результати досліджень відображено в таблиці 3.

При вивченні впливу концентрації екстрагенту встановлено, що найбільш повне вилучення визначених нами маркерів діючих речовин із сировини квіток хризантеми садової сорту Пектораль забезпечує 70 \% етанол.

Таблиця 3 - Вплив концентрації етанолу на вилучення діючих речовин із квіток хризантеми садової сорту Пектораль

\begin{tabular}{|c|c|c|c|}
\hline \multirow{2}{*}{$\begin{array}{l}\text { Концентрація } \\
\text { етанолу, \% }\end{array}$} & \multicolumn{3}{|c|}{ "Вміст діючих речовин } \\
\hline & $\begin{array}{c}\text { сума гідроксикоричних } \\
\text { кислот, \% }\end{array}$ & $\begin{array}{c}\text { сума френольних } \\
\text { сполук, \% }\end{array}$ & $\begin{array}{c}\text { сума } \\
\text { фрлавоноїдів, \% }\end{array}$ \\
\hline 60 & $8,97 \pm 0,01$ & $10,37 \pm 0,03$ & $5,57 \pm 0,02$ \\
\hline 63 & $8,08 \pm 0,03$ & $9,27 \pm 0,02$ & $7,23 \pm 0,02$ \\
\hline 65 & $8,82 \pm 0,03$ & $8,19 \pm 0,04$ & $6,67 \pm 0,05$ \\
\hline 68 & $9,28 \pm 0,05$ & $10,86 \pm 0,01$ & $8,62 \pm 0,01$ \\
\hline 70 & $9,53 \pm 0,02$ & $11,09 \pm 0,02$ & $8,84 \pm 0,02$ \\
\hline 73 & $8,92 \pm 0,01$ & $10,41 \pm 0,03$ & $7,52 \pm 0,03$ \\
\hline 75 & $8,49 \pm 0,01$ & $9,92 \pm 0,01$ & $7,22 \pm 0,01$ \\
\hline
\end{tabular}

ВИСНОВКИ. 1. На основі математичного планування експерименту вивчено закономірності вилучення діючих речовин із квіток хризантеми садової сорту Пектораль залежно від концентрації використаного екстрагенту, співвідношення вихідна сировина/екстрагент і методу екстрагування.
2. Встановлено, що оптимальним способом отримання екстракту з квіток хризантеми садової сорту Пектораль є метод дробної мацерації 70 \% етанолом при співвідношенні лікарська рослинна сировина/екстрагент 1:8.

\section{СПИСОК ЛІТЕРАТУРИ}

1. Васенда М. М. Сучасний стан виробництва орітопрепаратів / М. М. Васенда // Фармац. часоп. 2013. - № 4. - C. 143-147.

2. Москаленко Д. Фітотерапія: стан и перспективи розвитку [Електронний ресурс] / Д. Москаленко // Здоров'я України. - 2003. - № 81. - Режим доступу до журн. : http://www.health-ua.org/archives/health/407.html.

3. GS/MS analysis of fatty acids in flowers and leaves of Chrysanthemum×hortorum Bailey Belgo and Pectoral' variants. / S. Marchyshyn, O. Polonets, O. Zarichanska, M. Garnyk // The Pharma Innovation International Journal. - 2017. - 6, Issue 11, Part G. - P. 463-466.

4. Дослідження френольних сполук хризантеми садової багаторічної (Chrysanthemum $\times$ hortorum Bailey) / С. М. Марчишин, О. Л. Демидяк, О. В. Полонець, М. С. Гарник // Мед. та клініч. хімія. -2016. - 18, № 2 (68). - C. 48-53.

5. Identification and quantification of the sedative and anticonvulsant flavone glycoside from Chrysanthemum boreale / A. Nurgoho, S.-C. Lim, J. Choi [et al.] // Archives of Pharmacol Research. - 2013. - No. 36. P. 51-60.

6. Study of the morphological and anatomic signs of the flowers of the Chrysanthemum hortorum Dailey sort Pectoral (pharmacognostic analysis) / S. Marchyshyn, O. Polonets, M. Harnyk, L. Sira// Scientific Journal "Scien-
ceRise: Pharmaceutical Science". -2020. - No. 4 (26). P. 47-53.

7. Marchyshyn S. Investigation of essential oils of decorative herbs / S. Marchyshyn, O. Demydiak, H. Kozyr [et al.] // Natural Volaties \& essential oils: 46-th international symposium on essential oils, 13-16 September, 2015. - 2, Issue 3. - P. 104.

8. Державна Фармакопея України / Державне підприємство “Український науковий фрармакопейний центр якості лікарських засобів". - 2-ге вид. - Харків : Державне підприємство "Український науковий фрармакопейний центр якості лікарських засобів", 2015. 1. $-1128 \mathrm{c}$

9. Математичне планування експерименту при проведенні наукових досліджень в фрармації / [Т. А. Грошовий, В. П. Марценюк, Л. І. Кучеренко та ін.]. - Тернопіль : ТДМУ, 2008. - 368 с.

10. Теорія і практика екстрагування у фармацевтичній і харчовій промисловостях / [Т. М. Вітенько, Л. В. Соколова, Н. М. Белей та ін.]. - Тернопіль : Крок, 2012. - 200 c.

11. Гарна С. В. Взаємозв'язок основних технологічних параметрів рослинної сировини / С. В. Гарна, П. П. Вєтров, В. А. Георгіянц // Актуальні питання фрармац. і мед. науки та практики. - 2012. - № 1 (8). C. $54-58$. 
12. Дослідження деяких технологічних параметрів Хризантеми листя та квітів для створення нової лікарської субстанції / Г. Козир, О. Полонець, Ю. Крав- ченко, Ю. Каріна // Хімія природних сполук : матеріали V Всеукр. наук.-практ. конф. 3 міжнар. участю, 30-31 трав. 2019 р. - Тернопіль, 2019. - С. 130-131.

\section{REFERENCES}

1. Vasenda, M.M. (2013). Suchasnyi stan vyrobnytstva fitopreparativ [The current state of production of phytopreparations]. Farmatsevtychnyi chasopys - Pharmaceutical Review, 4, 143-147 [in Ukrainian].

2. Moskalenko, D. (2003). Fitoterapiia: stan i perspektyvy rozvytku [Phytotherapy: state and prospects of development]. Zdorovia Ukrainy - Health of Ukraine, 81. Retrieved from: http://www.health-ua.org/archives/ health/407.html [in Ukrainian].

3. Marchyshyn, S., Polonets, O., Zarichanska, O., Garnyk, M. (2017). GS/MS analysis of fatty acids in flowers and leaves of Chrysanthemum $\times$ hortorum Bailey Belgo and Pectoral' variants. The Pharma Innovation International Journal, 6 (11), Part G, 463-466.

4. Marchyshyn, S.M., Demydyak, O.L., Polonecz, O.V., \& Garnyk, M.S. (2016). Doslidzhennia fenolnykh spoluk khryzantemy sadovoi bahatorichnoi (Chrysanthemum $\times$ hortorum Bailey) [Study of phenolic compounds of Chrysanthemum garden perennial (Chrysanthemum $\times$ hortorum Bailey)]. Medychna ta klinichna khimiia - Medical and Clinical Chemistry, 18 (2), 48-53 [in Ukrainian]

5. Nurgoho, A., Lim, S.-C., \& Choi, J. (2013). Identification and quantification of the sedative and anticonvulsant flavone glycoside from Chrysanthemum boreale. Archives of Pharmacol. Research, 36, 51-60.

6. Marchyshyn, S., Polonets, O., Harnyk, M., Sira, L. (2020). Study of the morphological and anatomic signs of the flowers of the Chrysanthemum hortorum Dailey sort Pectoral (pharmacognostic analysis). Scientific Journal "ScienceRise: Pharmaceutical Science", 4 (26), 47-53.

7. Marchyshyn, S., Demydiak, O., Kozyr, H., Berdei, T., Dakhym, I., Polonets, O., \& S. Marchyshyn (2015). Investigation of essential oils of decorative herbs. Natural volaties \&essential oils: 46-th International Symposium on Essential Oils. September, 13-16.
8. (2015). Derzhavna Farmakopeia Ukrainy. Derzhavne pidpryiemstvo "Ukrainskyi naukovyi farmakopeinyi tssentr yakosti likarskykh zasobiv". 2-e vyd. [State Pharmacopoeia of Ukraine. State Enterprise "Ukrainian Scientific Pharmacopoeial Center for Quality of Medicines". 2nd type]. Kharkiv: Derzhavne pidpryiemstvo "Ukrainskyi naukovyi farmakopeinyi tsentr yakosti likarskykh zasobiv" [in Ukrainian].

9. Hroshovyi, T.A., Martseniuk, V.P., Kucherenko, L.I., Vronska, L.V., \& Hureieva, S.M. (2008). Matematychne planuvannia eksperymentu pry provedenni naukovykh doslidzhen $v$ farmatsii [Mathematical planning of an experiment in conducting research in pharmacy]. Ternopil: Ukrmedknyha [in Ukrainian].

10. Vitenko, T.M., Sokolova, L.V., \& Belei, N.M. (2012). Teoriia i praktyka ekstrahuvannia u farmatsevtychnii i kharchovii promyslovostiakh [Theory and practice of extraction in the pharmaceutical and food industries]. Ternopil: V-vo "Krok" [in Ukrainian].

11. Harna, S.V., Vietrov, P.P., \& Heorhiiants, V.A. (2012). Vzaiemozviazok osnovnykh tekhnolohichnykh parametriv roslynnoi syrovyny [Relationship between the main technological parameters of vegetable raw materials]. Aktualni pytannia farmatsevtychnoi i medychnoi nauky ta praktyky - Current Issues of Pharmaceutical and Medical Practice, 1 (8), 54-58 [in Ukrainian].

12. Kozyr, H.R., Polonets, O., Kravchenko, Yu., \& Karina, Yu. (2019). Doslidzhennia deiakykh tekhnolohichnykh parametriv khryzantemy lystia ta kvitiv dlia stvorennia novoi likarskoi substantsii [Study of some technological parameters of Chrysanthemum leaves and flowers to create a new medicinal substance]. Khimiia pryrodnikh spoluk: Materialy V Vseukrainskoi naukovo-praktychnoi konferentsii z mizhnarodnoiu uchastiu - Chemistry of Natural Compounds: Materials of V All-Ukrainian Scientific-practical Conference with International Participation. May, 30-31.Ternopil 58 [in Ukrainian].

Г. Р. Козыр, Ю. В. Карина ТЕРНОПОЛЬСКИЙ НАЦИОНАЛЬНЫЙ МЕДИЦИНСКИЙ УНИВЕРСИТЕТ ИМЕНИ И. Я. ГОРБАЧЕВСКОГО МОЗ УКРАИНЫ

\section{ТЕХНОЛОГИЧЕСКИЕ АСПЕКТЫ ПОЛУЧЕНИЯ ЭКСТРАКТА ИЗ ЦВЕТКОВ ХРИЗАНТЕМЫ САДОВОЙ СОРТА ПЕКТОРАЛЬ}

\section{Резюме}

Вступление. Хронический стресс, раздражительность и нарушение сна снижают качество жизни человека, ослабляют иммунитет, повышают риск развития воспалительных заболеваний. Поэтому растет спрос на лекарственные средства растительного происхождения и возникает необходимость расширить их ассортимент. Иностранные источники свидетельствуют о перспективности использо- 
вания цветков хризантемы в качестве седативного и противосудорожного средства. Поэтому перспективной была разработка технологии получения экстракта из цветков хризантемы садовой.

Цель исследования - изучить влияние некоторых фрармачевтических фракторов на степень извлечения действующих веществ из цветков хризантемы садовой сорта Пектораль для разработки технологии получения сухого экстракта на основе этого растения, который в дальнейшем будут использовать как полупродукт в производстве новых лекарственных фоорм.

Методы исследования. Изучено влияние на степень извлечения биологически активных веществ таких фрармацевтических фракторов, как природа экстрагента, соотношение исходное сырье/экстрагент и метод экстрагирования. Критериями оценки полученных сухих субстанций служили количественное содержание суммы френольных соединений (пересчет на галловую кислоту), количественное содержание суммы фрлавоноидов (пересчет на рутин) и количественное содержание суммы гидроксикоричных кислот (пересчет на хлорогеновую кислоту), которые определяли спектрофоотометрическим методом на спекmрофотометре Lambda 25 Perkin Elmer.

Результаты и обсуждение. На основе математического планирования эксперимента изучено закономерности извлечения френольных соединений, фрлавоноидов и гидроксикоричных соединений из цветков хризантемы садовой сорта Пектораль в зависимости от концентрации использованного экстрагента этанола, соотношения сырье/экстрагент и метода экстрагирования.

Вывод. Установлено, что оптимальным способом получения экстракта из цветков хризантемы садовой сорта Пектораль является метод дробной мацерации 70 \% этанолом при соотношении лекарственное растительное сырье/экстрагент 1:8.

КЛЮЧЕВЫЕ СЛОВА: хризантема садовая; цветки; экстракт; технологические параметры.

H. R. Kozyr, Yu. V. Karina

I. HORBACHEVSKY TERNOPIL NATIONAL MEDICAL UNIVERSITY

\section{TECHNOLOGICAL ASPECTS OF OBTAINING EXTRACT FROM FLOWERS OF GARDEN CHRYSANTHEMUM VARIETY PECTORAL}

\section{Summary}

Introduction. Chronic stress, irritability and sleep disorders reduce the quality of life, weaken the immune system, increase the risk of various inflammatory diseases. Therefore, the demand for herbal medicines is growing and there is a need to expand their range. Foreign sources indicate the prospects of using chrysanthemum flowers as a sedative and anticonvulsant. Therefore, the development of technology for obtaining an extract from the flowers of garden Chrysanthemum was promising.

The aim of the study - to learn the influence of some pharmaceutical factors on the degree of extraction of active substances from flowers of garden Chrysanthemum variety Pectoral to develop a technology for obtaining a dry extract based on this plant, which will be used as an intermediate in the production of new dosage forms.

Research Methods. The influence of such pharmaceutical factors on the degree of BAS extraction as the nature of the extractant, the ratio of raw materials: extractant and the method of extraction was studied. The evaluation criteria for the obtained dry substances were the quantitative content of the sum of phenolic compounds (in terms of gallic acid), the amount of flavonoids (in terms of rutin) and the amount of hydroxycinnamic acids (in terms of chlorogenic acid), determined by spectrophotometric method on a spectrophotometer Lambda 25 Perkin Elmer.

Results and Discussion. On the basis of mathematical planning of the experiment the regularities of extraction of phenolic compounds, flavonoids and hydroxycinnamic compounds from flowers of Chrysanthemum garden variety Pectoral depending on the concentration of used ethanol extractant, ratio of raw materials: extractant and extraction method were studied.

Conclusion. It was determined that the optimal method of obtaining an extract from the flowers of the garden Chrysanthemum variety Pectoral is the method of fractional maceration with $70 \%$ ethanol at a ratio of "LRS:extractant" 1:8.

KEY WORDS: garden chrysanthemum; flowers; extract; technological aspects.

Адреса для листування: Г. Р. Козир, Тернопільський національний медичний університет імені І. Я. Горбачевського МОз України, майдан Волі, 1, Тернопіль, 46001, Україна, e-mail: kozyr@tdmu.edu.ua. 